\title{
ADVENTITIOUS ROOTING COMPETENCE AND RESCUE OF ADULT MATE PLANTS BY CUTTINGS ${ }^{1}$
}

\author{
Dilson Antônio Bisognin ${ }^{2 *}$, Kelen Haygert Lencina ${ }^{3}$, Leandro Vinicius da Luz ${ }^{2}$ Frederico Dimas Fleig ${ }^{4}$ and \\ Denise Gazzana ${ }^{5}$

\footnotetext{
${ }^{1}$ Received on 13.04.2018 accepted for publication on 13.08.2018.

${ }^{2}$ Universidade Federal de Santa Maria, Departamento de Fitotecnia, Santa Maria, RS-Brasil. E-mail: <dilson.bisognin@ufsm.br>. ${ }^{3}$ Universidade Federal de Santa Maria, Doutor em Engenharia Florestal, Santa Maria, RS-Brasil. E-mail: $<$ khaygert@hotmail.com> and <leandrodaluz_5@hotmail.com>.

${ }^{4}$ Universidade Federal de Santa Maria, Departamento de Ciências Florestais, Santa Maria, RS-Brasil. E-mail: <fdfleig@smail.ufsm.br>. ${ }^{5}$ Universidade Federal de Santa Maria, Programa de Pós-Graduação em Engenharia Florestal, Santa Maria, RS-Brasil. Email:<denygazzana@hotmail.com>.

*Corresponding author.
}

\begin{abstract}
The competence of adult plants of mate (Ilex paraguariensis St. Hil.) to undergo adventitious rooting is essential to their vegetative rescue by cuttings. This study aimed to evaluate the adventitious rooting competence of adult mate plants, and then rescue these plants by making cuttings from epicormic shoots induced in different trunk positions. The percent survival and rooting of cuttings from epicormic shoots induced by girdling in seven adult plants were evaluated. The two stock plants whose cuttings had the highest rooting competence were further pruned and girdled to evaluate the effect of the position of epicormic shoots on their adventitious rooting competence. The potential success of rescuing of the same adult plants was also studied with cuttings of epicormic shoots induced by coppicing. The shoots were sectioned in single-bud cuttings, either treated with $3,000 \mathrm{mg} \mathrm{L}^{-1}$ indolebutyric acid or untreated, and then cultivated in a humid chamber for 60 days, and then the percent survival and rooting of cuttings was evaluated. In conclusion, we found that it is possible to rescue adult mate plants by cuttings from epicormic shoots induced by pruning, girdling, or coppicing. The adventitious rooting competence of cuttings differs among adult mate plants, and depends on the position of the epicormic shoots on the trunk from which epicormic shoots are collected.
\end{abstract}

Keywords: Girdling; Coppicing; Epicormic shoots.

\section{COMPETÊNCIA AO ENRAIZAMENTO ADVENTÍCIO E RESGATE DE PLANTAS ADULTAS DE ERVA-MATE POR ESTAQUIA}

RESUMO - A competência ao enraizamento adventício é essencial para viabilizar o resgate vegetativo de plantas adultas de erva-mate (Ilex paraguariensis St. Hil.). Os objetivos deste trabalho foram avaliar plantas adultas de erva-mate para a competência ao enraizamento adventicio e estudar o resgate destas plantas, por estaquia de brotações epicórmicas, induzidas em diferentes posições do tronco. Sete plantas adultas foram avaliadas quanto à porcentagem de sobrevivência e enraizamento das estacas, oriundas de brotações induzidas pelo anelamento do tronco. Duas plantas que apresentaram a maior competência ao enraizamento foram submetidas à poda da parte aérea e ao anelamento da base, para estimular novas brotações epicórmicas e avaliar o efeito da posição de coleta no enraizamento das estacas. O resgate por estaquia, das mesmas plantas, também foi estudado em brotações epicórmicas induzidas pela decepa. As brotações foram seccionadas em estacas de gema única, tratadas ou não com $3.000 \mathrm{mg} \mathrm{L}^{-1}$ de ácido indolbutirico e mantidas em câmara úmida por 60 dias. As estacas foram avaliadas quanto as porcentagens de sobrevivência e enraizamento. Concluiu-se que é possível resgatar plantas adultas de erva-mate por estaquia de brotações epicórmicas induzidas por poda, anelamento ou decepa. Plantas adultas de erva-mate diferem quanto a competência ao enraizamento adventício das estacas e também quanto a posição de coleta das brotações epicórmicas.

Palavras-Chave: Anelamento; Decepa; Brotações epicórmicas.

Revista Árvore. 2018;42(3):e420312 


\section{INTRODUCTION}

Increasing interest in the products of mate plants (Ilex paraguariensis St. Hil.) and their many possible uses suggest that there will be an increase in demand for higher quality raw materials of this plant by various industries. Raw materials are harvested from both native and planted forests, which are established with seminal seedlings. Because mate is a dioecious species, forests established from seminal seedlings have high genetic variability, which negatively affects the quality of raw mate products and hinders the establishment of any industrial standards. However, vegetative propagation of plantlets allows favorable combinations of traits, specific chemical compositions, superior genetic variances, and high levels of heterozygosity to be fixed (Bisognin, 2011), because with this approach individuals genetically identical to the parental plant can be obtained. Therefore, the use of plantlets obtained by the vegetative propagation of selected genotypes would be advantageous for the industry, and these should be used to establish new forest stands of mate, because they would result in more uniform, productive, and high-quality harvests (Silva et al., 2007). In addition, vegetative propagation has the potential to aid in the conservation of superior genotypes and would allow for the production of plantlets of high genetic and phytosanitary quality throughout the year (Xavier et al., 2013).

Among the most important traits for selecting stock plants of mate are the yield and quality of the green mass, resistance to pests and diseases, and type and architecture of the canopy (Resende et al., 2000). These traits are expressed in adult plants, which present a series of ontogenetic physiological changes associated with the phase they are at in their developmental cycle, as well as aging. One of the most consistent signs of plant tissue maturity or aging is the reduction or loss of the competence of cuttings to undergo adventitious rooting (Wendling et al., 2014), which limits the ability of vegetative propagation to be used for rescuing adult plants (Hartmann et al., 2011). Additionally, in woody species there is a gradient in the maturation of the tissues from the base towards the apex of the plant, in which the apical buds are relatively more mature than those that grow from the basal part of the trunk; however, there are large variations in this pattern at the intra- and interspecific levels (Hartmann et al., 2011; Xavier et al., 2013). The basal buds are developed at the same time as seed germination occurs, and thus the tissues in them maintain juvenile characteristics (Hartmann et al., 2011).

Rescue of adult plants by vegetative propagation can be accomplished by the induction of the development of epicormic and adventitious shoots. Epicormic buds develop from dormant axillary buds (Seitz, 1995) after the breaking, removal, or death of branches along the trunk increases the incident light level at these buds. Moreover, their induction may also result from the morphogenesis of cambium cells, which gives rise to new sprouts (Rast etal., 1988). Adventitious shoots originate at sites other than those that would form buds and branches in the natural course of plant development. Shoots formed at the basal region of the trunk exhibit juvenility, in that they are physiologically more competent to undergo adventitious rooting than those formed at other parts of the plant, and show relatively higher growth vigor (Wendling et al., 2014). The formation of adventitious shoots is induced in adult plants by setting fire to or girdling the base of the trunk, or by coppicing the tree (Almeida et al., 2007; Wendling et al., 2013; Stuepp et al., 2016).

In addition to the abovementioned maturation gradient, the rooting competence of cuttings varies among mate plants (Sturion and Resende, 1997) as a result of differences in the genes involved in the control mechanism of the adventitious root formation process (Assis and Teixeira, 1998). Thus, the identification of mate plants with high adventitious rooting competence, together with the definition of an efficient method for rescuing selected adult plants from the induction of epicormic shoots to rooting by cuttings, are important scientific and technological contributions to the development of better methods for the vegetative propagation of selected mate plants. Therefore, the aims of this study were to evaluate the adventitious rooting competences of adult mate plants and to rescue these plants by taking cuttings from epicormic shoots induced in different positions along the trunk.

\section{MATERIALAND METHODS}

Experiments were carried out from August 2013 to July 2017 at the Center of Plant Breeding and Vegetative Propagation of the Department of Plant Sciences of the Federal University of Santa Maria (UFSM), Brazil. At the beginning of the experiment, we evaluated ten 18-year-old adult mate plants that had been growing in an experimental area maintained by the Department of Forestry Sciences of UFSM.

Revista Árvore. 2018;42(3):e420312 
In all experiments, shoots were collected and sectioned in single-bud cuttings containing a leaf reduced to $50 \%$ of its original length. Cuttings were immersed for $10 \mathrm{~s}$ in either distilled water or a hydroalcoholic solution of $3,000 \mathrm{mg} \mathrm{L}^{-1}$ indolebutyric acid (IBA). The cuttings were cultivated in 128-well polyethylene trays containing equal proportions of commercial substrate (peat moss and carbonized rice hulls) and vermiculite. The trays were kept in a humid chamber, with an average temperature of $27^{\circ} \mathrm{C}$ and a relative humidity of approximately $85 \%$ maintained by nebulizers that were automatically activated 12 times a day for $10 \mathrm{~min}$, with an airflow of $10 \mathrm{~m}^{3} \mathrm{~min}^{-1}$. After 60 days of cultivation, the percentages of the cuttings that survived and rooted were calculated.

Ten 18-year-old mate plants were girdled in August 2013 to induce the development of epicormic shoots at the base of the trunk. To do this, a portion of the bark was removed around the entire circumference of the trunk. The removed portion of bark was approximately $3 \mathrm{~cm}$ wide and $0.5 \mathrm{~cm}$ thick, and located between 10 and $20 \mathrm{~cm}$ above the ground. Approximately 200 days later, the shoots that developed on seven stock plants (13SM01, 13SM03, 13SM05, 13SM06, 13SM07, 13SM08, and 13SM09) were harvested, which produced enough cuttings to evaluate their rooting competence. In this experiment, all cuttings were treated with $3,000 \mathrm{mg} \mathrm{L}$ ${ }^{1}$ IBA. The experiment was carried out in a completely randomized design, with five replicates used for each of the five cuttings.

The stock plants with the highest rooting competence were selected and used to evaluate the effect of the trunk position of the induced epicormic shoots on the rooting of the cuttings produced from them. For this test, all branches of the 13SM01 and 13SM05 stock plants were pruned to approximately $50 \mathrm{~cm}$ in length, and then the plants were girdled again to induce the development of new epicormic shoots. The shoots were collected in December 2014, and identified according to their position in the trunk as below the girdled area, or on the lower, middle or upper third of the plant. In this experiment, the percentage of cuttings undergoing rooting was evaluated after $45,60,75,90$, and 105 days of cultivation in a humid chamber. Along with the percent of cuttings rooting, the daily current increment (DCI) of rooting, which determines the point of maximum rooting, was calculated according to Ferreira et al. (2004) as DCI $=\mathrm{X}_{(i+1)}-\mathrm{X}_{(i)}$, where: $i=$ time of evaluation; $\mathrm{X}_{(i+1)}$
$=$ percent of cuttings rooting at time $(i+1)$; and $\mathrm{X}_{(i)}$ $=$ percent of cuttings rooting at the evaluation time. The experiment had a three-way factorial design that examined all combinations of four trunk positions, two concentrations of IBA, and two stock plants. Individual experimental units were distributed in a completely randomized design, with eight replicates used for each of the eight different types of cutting.

The stock plants 13SM01 and 13SM05 were also submitted to coppicing in January 2017 for the induction of new epicormic shoots, which were then collected in May 2017. The experiment had a two-way factorial design combining two concentrations of IBA and two stock plants, distributed in a completely randomized design with ten replicates of each of six types of cutting.

Data were tested for normality of residuals with the Shapiro-Wilk test, and then subjected to analysis of variance (ANOVA). Different levels of any factor that were found to lead to significant differences in the variables tested by the ANOVA F-test $(\mathrm{p}<0.05)$ were further compared using Tukey's test, with a 5\% type-I error probability $(p<0.05)$. All analyses were done with R-Studio software, version 1.0.143.

\section{RESULTS}

Adult mate plants evaluated for the adventitious rooting competence of shoots induced by girdling showed significant differences in the percent survival and rooting of their cuttings (Table 1). All cuttings produced by the stock plants 13SM01, 13SM05, and 13SM07 remained alive after 60 days of cultivation in a humid chamber. These plants did not significantly differ from 13SM03, the cuttings of which had an $88 \%$ survival. There was wide variation in the rooting competence of cuttings among the stock plants, which varied from $0 \%$ for $13 \mathrm{SM} 08$ (in spite of the high (60\%) survival of its cuttings) to $76 \%$ for $13 \mathrm{SM} 05$. The highest percent rooting was observed in cuttings of the 13SM05 and 13SM01 stock plants, which significantly differed from all other stock plants. The stock plants 13SM03, 13SM06, 13SM07, 13SM08, and 13SM09 did not significantly differ from one another, and had rooting percentages ranging from $0 \%$ to $12 \%$.

There was no significant three-way interaction among the effects of the position of the adventitious shoots on the trunk, the use of IBA, and the stock plant on either percent survival or rooting of the cuttings. 
Table 1 - Percentages of cuttings from adult mate plants surviving and rooted after 60 days of cultivation in a humid chamber.

Tabela 1 - Porcentagens de sobrevivência e enraizamento de estacas oriundas de plantas adultas de ervamate, aos 60 dias de cultivo em câmara úmida.

\begin{tabular}{ccc}
\hline Stock plant & Survival (\%) & Rooting (\%) \\
\hline 13SM05 & $100.0 \mathrm{a} *$ & $76.0 \mathrm{a}$ \\
13SM01 & $100.0 \mathrm{a}$ & $68.0 \mathrm{a}$ \\
13SM07 & $100.0 \mathrm{a}$ & $12.0 \mathrm{~b}$ \\
13SM03 & $88.0 \mathrm{ab}$ & $8.0 \mathrm{~b}$ \\
13SM06 & $60.0 \mathrm{bc}$ & $8.0 \mathrm{~b}$ \\
13SM09 & $52.0 \mathrm{c}$ & $4.0 \mathrm{~b}$ \\
13SM08 & $60.0 \mathrm{bc}$ & $0.0 \mathrm{~b}$ \\
Mean & 80.0 & 25.1 \\
CV $(\%)$ & 19.8 & 59.3 \\
* Means followed by the same letter did not significantly differ $(\mathrm{p}$
\end{tabular}

$>0.05$ ) according to Tukey's test.

However, there was a significant interaction between the use of IBA with both the stock plant and the position of the adventitious shoots on the trunk (Table 2). The highest survival was observed for the cuttings of the 13SM05 plant, while the application of IBA favored the survival of the cuttings of the $13 \mathrm{SM} 01$ plant. The 13SM05 plant had the greatest competence to produce roots, and the application of IBA increased the percent rooting of cuttings from both stock plants. The position of the adventitious shoots on the trunk did not affect the survival of their cuttings, with the exception of those produced below the girdled area and treated with IBA. Treatment with $3,000 \mathrm{mg} \mathrm{L}^{-1}$ IBA increased the percent survival of cuttings from the lower and middle thirds of the trunk. Cuttings originating from shoots produced below the girdling area resulted in the highest rooting percentages, but did not differ from those produced from the median third of the trunk without IBA or from the lower third when treated with IBA.

Evaluating the percent rooting of cuttings from adventitious shoots produced in different positions on the trunk after 45, 60, 75, 90, and 105 days allowed us to estimate the daily current increment (DCI) and define the point of maximum rooting The maximum DCI was similar for the two stock plants and occurred after 60 days of cultivation for shoots produced from all evaluated positions (Figure 1). The DCI then decreased after this point, with this decline being more obvious for the 13SM05 plant, which presented the highest DCI for all collection positions evaluated after up to 75 days of cultivation. The DCI reached the minimum value after 90 days of cultivation for cuttings from the 13SM05 plant in the humid chamber, with the exception of cuttings produced from shoots collected from the upper third of this plant.

When rescuing adult plants from adventitious shoots induced by coppicing, there was no significant interaction between the effects of the stock plant and the application of IBA on the percent survival or rooting of the cuttings (Table 3). The application of IBA did not affect the survival of the cuttings from any of the evaluated plants, with the average survival of cuttings observed to be $55 \%$. The rooting percentage of cuttings from shoots produced after coppicing did not differ between the stock plants, but the application of $3,000 \mathrm{mg} \mathrm{L}^{-1}$ IBA increased the percentage of the cuttings that underwent rooting.

Table 2 - Percentages of cuttings from different portions of two stock mate plants, either treated with indolebutyric acid (IBA) or untreated, surviving and rooted after 60 days of cultivation in a humid chamber.

Tabela 2-Porcentagens de sobrevivência e enraizamento das estacas de duas plantas matrizes de erva-mate tratadas ou não com ácido indolbutírico (AIB) e coletadas de diferentes posições, aos 60 dias de cultivo em câmara úmida.

\begin{tabular}{|c|c|c|c|c|}
\hline \multirow[t]{2}{*}{ Treatment } & \multicolumn{2}{|c|}{ Survival (\%) } & \multicolumn{2}{|c|}{ Rooting (\%) } \\
\hline & $0 \mathrm{mg} \mathrm{L}^{-1} \mathrm{IBA}$ & $3,000 \mathrm{mg} \mathrm{L}^{-1} \mathrm{IBA}$ & $0 \mathrm{mg} \mathrm{L}^{-1} \mathrm{IBA}$ & $3,000 \mathrm{mg} \mathrm{L}^{-1} \mathrm{IBA}$ \\
\hline \multicolumn{5}{|l|}{ Stock plant } \\
\hline 13SM01 & $44.1 \mathrm{Bb} *$ & $62.1 \mathrm{Ab}$ & $0.8 \mathrm{Bb}^{*}$ & $8.6 \mathrm{Ab}$ \\
\hline 13SM05 & $89.8 \mathrm{Aa}$ & $89.4 \mathrm{Aa}$ & $28.4 \mathrm{Ba}$ & $43.7 \mathrm{Aa}$ \\
\hline \multicolumn{5}{|l|}{ Position } \\
\hline Below girdled & $64.8 \mathrm{Aa}^{*}$ & $57.8 \mathrm{Ab}$ & $27.7 \mathrm{Aa}^{*}$ & $36.0 \mathrm{Aa}$ \\
\hline Lower third & $54.8 \mathrm{Ba}$ & $78.9 \mathrm{Aa}$ & $7.2 \mathrm{Bb}$ & 27.2 Aab \\
\hline $\begin{array}{l}\text { Meddle third } \\
\text { Upper third }\end{array}$ & $62.5 \mathrm{Ba}$ & $85.1 \mathrm{Aa}$ & $24.4 \mathrm{Aa}$ & $22.1 \mathrm{Ab}$ \\
\hline Upper third & $75.8 \mathrm{Aa}$ & $81.2 \mathrm{Aa}$ & $3.6 \mathrm{Bb}$ & $21.1 \mathrm{Ab}$ \\
\hline Means & 64.5 & 75.7 & 15.7 & 26.6 \\
\hline $\mathrm{CV}(\%)$ & \multicolumn{2}{|c|}{19.9} & \multicolumn{2}{|c|}{29.1} \\
\hline
\end{tabular}

*Means followed by the same lowercase letter in each column or uppercase letter in each row did not significantly differ ( $\mathrm{p}>0.05)$ according to Tukey's test.

Revista Árvore. 2018;42(3):e420312 

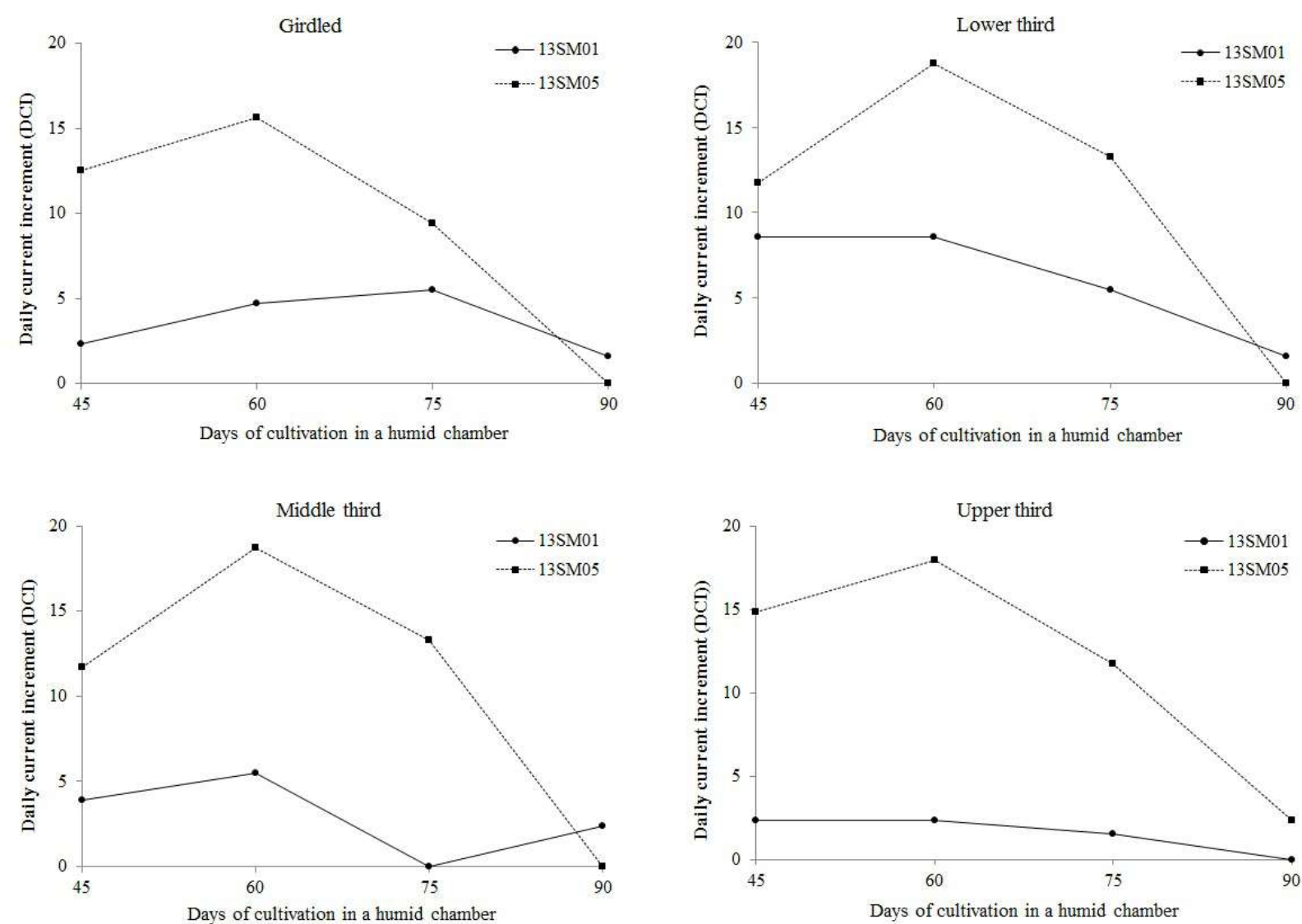

Figure 1 - Daily current increment (DCI) of rooting percentages of mate cuttings taken from different positions on two stock plants during cultivation in a humid chamber.

Figura 1 - Incremento corrente diário (ICD) da porcentagem de enraizamento de estacas de erva-mate, coletadas em diferentes posiçôes de duas plantas matrizes, em função do tempo de permanência em câmara úmida.

Table 3 - Percentages of cuttings from shoots induced by coppicing of two mate stock plants, either treated with indolebutyric acid (IBA) or untreated, surviving and rooted after 60 days of cultivation in a humid chamber.

Tabela 3 - Porcentagens de sobrevivência e enraizamento das estacas oriundas da decepa de duas plantas matrizes de erva-mate tratadas ou não com ácido indolbutírico (AIB), aos 60 dias de cultivo.

\begin{tabular}{ccc}
\hline Treatment & Survival (\%) & Rooting (\%) \\
\hline Stock plant & & \\
13SM01 & $51.7 \mathrm{a}^{*}$ & $51.8 \mathrm{a}$ \\
13SM05 & $59.2 \mathrm{a}$ & $41.0 \mathrm{a}$ \\
\hline IBA $\left(\mathrm{mg} \mathrm{L}^{-1}\right)$ & & \\
\hline 0 & $50.8 \mathrm{a}$ & $37.1 \mathrm{~b}$ \\
3,000 & $60.0 \mathrm{a}$ & $55.2 \mathrm{a}$ \\
Mean & 55.4 & 46.2 \\
CV $(\%)$ & 46.6 & 88.3 \\
\hline
\end{tabular}

* Means followed by the same letter did not significantly differ $(\mathrm{p}>0.05)$ according to Tukey's test.

\section{DISCUSSION}

The fact that the rooting competence of the adventitious shoots induced by girdling in this study depended on the stock plant or genotype (Table 1) was in agreement with observations made in other studies; this fact also explains the absence of rooting in the 13SM08 plant. Differences among genotypes were also previously verified for rooted cuttings of Toona ciliata var. australis (Pereira et al., 2015), and Eucalyptus benthamii and E. dunnii (Brondani et al., 2012). In Quercus acutissima, differences among genotypes were critical to the propagation of this species by cuttings, and the variation in the percentages of rooting of cuttings was as wide as $80 \%$ (Moon and Yi, 1993), which was very similar to the range observed in the present study (from $0 \%$ to $76 \%$ ). Therefore, these results confirmed that the rooting competence of cuttings varies among 
genotypes (Kibbler et al., 2004). In the case of adult mate plants, it is very important to know the rooting competence of a particular genotype, as this is an essential determinant of the likely success of vegetative propagation by cuttings. Therefore, it is necessary to adopt early selection strategies when breeding new clones, mainly to eliminate recalcitrant genotypes in vegetative propagation. This matters because the identification of genotypes with greater competence for adventitious rooting is extremely important for successful vegetative propagation; for example, as part of a selection strategy in breeding programs for the vegetative propagation of mate by cuttings, those genotypes that do not grow roots or shoots must be discarded early on. In Eucalyptus cloeziana, a previous study showed that adventitious rooting should be used as an auxiliary criterion in breeding programs that provides greater selection gains because of high heritability of this trait; however, studies related to the selection of genotypes for adventitious rooting competence in this species are still in the early stages of development (Oliveira et al., 2015).

In this study, shoots were collected from positions below and above a girdling area, where a portion of the bark around the entire trunk's circumference was removed to stimulate the growth of new shoots. All shoots collected below the girdled area were thus formed in the more juvenile portion of the plant, because it is close to the basal meristems formed at the time of seed germination (Hartmann et al., 2011). However, as one moves along the trunk in the direction of the shoot apex the cells become progressively more mature, as they accumulate the effects of the various cell divisions that occurred during development. Thus, it is believed that plants with no competence for rooting or with low percentage of rooting of cuttings from epicormic shoots produced below a girdling area will also not produce roots from cuttings of shoots produced in any other position on the trunk (Hartmann et al., 2011). Based on this premise and the fact that cuttings of the stock plants 13SM01 and 13SM05 presented 100\% survival and the highest percent rooting, we selected these plants to further study the effect of the shoot position on the trunk on rooting success, as they appeared to be the most promising genotypes for use in vegetative propagation of mate by cuttings.

The application of IBA increased the survival of cuttings from the 13SM01 plant, which presented the lowest competence for adventitious rooting of those tested (Table 2). This result may be associated with the catalytic effect of auxin, which would have stimulated and accelerated the adventitious rooting of cuttings and making them more suitable for absorbing water and nutrients from the substrate and less susceptible to dehydration and death. This is because auxin promotes the initiation of root primordia formation, in addition to acting on the movement of nutrients toward the growing tissue and interfering with the accumulation of other compounds necessary for rooting (Costa et al., 2013). This also explains the beneficial effect of the application of $3,000 \mathrm{mg} \mathrm{L}^{-1}$ IBA on the percentages of cuttings from both evaluated plants that underwent rooting.

Although the adventitious rooting process in both stock plants was favored by the application of IBA, a greater percentage of cuttings from 13SM05 rooted than those from 13SM01 did (Table 2). As discussed earlier, variation in rooting competence is expected among individual plants and is due to the influence of genetic effects on endogenous mechanisms involved in the rooting process (Mankessi et al., 2009). From this perspective, the differences observed confirmed that genetic variability existed between plants and was responsible for the differences in the rooting competence of cuttings between these two genotypes, which was not detected in the first experiment. In addition, because the plants were of a similar chronological age it is possible that differences in the rooting competence of their cuttings were related to their ontogenetic characteristics (Wendling and Xavier, 2001) and differences in their physiological conditions (Husen and Pal, 2007; Li et al., 2009). Significant effects of ontogenetic age on rooting success were also observed in a previous study of cuttings of Solanum tuberosum, an annual species that is highly receptive to vegetative propagation by cuttings, in which propagules from juvenile plants had higher rooting competence compared to cuttings from mature plants (Bisognin et al., 2015). Thus, there is possibly an important genetic component to ontogenetic maturation patterns and their effects on the rooting competence of mate cuttings. This hypothesis was corroborated by the variations we observed in the rooting responses of cuttings from shoots produced from different positions on the trunk, which was possibly because of the gradient of maturation in the plant that is commonly observed in perennial plants (Hartmann et al., 2011).

Revista Árvore. 2018;42(3):e420312 
Shoots produced below the girdling area and in the middle third of the plant showed the highest competence for rooting by their cuttings (Table 2). This was because of the juvenility and high vigor of the buds induced at the base of the plant, and justifies the use of these less developed shoots for rescuing adult plants of mate. The higher juvenility of these shoots is because of the presence of lateral buds at the base of the plant, which are more similar to the tissue formed during seed germination and thus favor the formation of new tissues, such as adventitious roots (Hartmann et al., 2011). Additionally, in some (mainly woody) species there is a maturation gradient towards the apex of the plant (Eldridge et al., 1994), which explains the lower competence for rooting of cuttings taken from shoots produced in the upper third of the plant. These observations suggest that maturity has a cellular basis and is a function of cumulative cell divisions (Greenwood and Hutchison, 1993). Further, the effect of IBA on rooting by cuttings was found to depend on the position of the shoot, with a stronger effect being observed in shoots from the upper third of the plant and a weaker effect in those formed below the girdling area.

The 13SM05 stock plant presented the highest daily increment (DCI) of rooting for all collection positions in the trunk (Figure 1), with the maximum DCI reached after 60 days of cultivation in a humid chamber. Knowing the maximum DCI of rooting by cuttings is important, as it indicates when the adventitious rooting competence of different genotypes/plants should be compared (Ferreira et al., 2004). In vegetative propagation, it is common to overestimate the time necessary for rooting by cuttings, without considering the negative effects of high humidity and temperature on shoot growth and adventitious rooting, as well as the fact that these conditions provide favorable conditions for the progression of most plant diseases (Brondani et al., 2012). Disease occurrence during the rooting process negatively affects the quality and number of plantlets produced by increasing the mortality of rooted cuttings.

The application of 3,000 $\mathrm{mg} \mathrm{L}^{-1}$ IBA also increased the percentage of cuttings from epicormic shoots induced by coppicing that rooted (Table 3 ). This again indicates the need for IBA application when rescuing adult mate plants, even those submitted to coppicing. In previous studies, the use of IBA also promoted the adventitious rooting of cuttings of Spondias tuberosa (Dutra et al., 2012), Gmelina arborea (Singh and Ansari, 2014), and cuttings from epicormic shoots of Tectona grandis (Husen and Pal, 2007), confirming the importance of IBA for rescuing adult plants of woody species.

The survival and rooting of cuttings from the 13SM01 and 13SM05 stock plants used in this study did not differ, as was also found for cuttings produced from shoots collected after girdling (Table 1). The induction of epicormic shoots by coppicing resulted in rooting percentages similar to those obtained by girdling (Table 1) and greater than those of shoots collected below the girdling area, especially from the 13SM01 plant (Table 2). The 13SM01 plant presented a similar adventitious rooting potential for cuttings from different trunk positions, which is an indication of the absence of cofactors or the presence of compounds that decrease the rooting competence of cuttings, as was claimed by Bitencourt et al. (2009) to explain the low rooting percentage of cuttings of adult mate plants. Moreover, considering that epicormic shoots induced by girdling or coppicing are produced from dormant buds at the base of the trunk, and therefore can be considered more juvenile, it is possible that the higher rooting competence we observed was due to the reinvigoration promoted by the elimination of the aerial part of the plant by coppicing. This behavior was not observed for the 13SM05 plant, which probably indicates that this plant presented greater juvenility than the 13SM01 one, though both stock plants were of a similar chronological age. These results indicate the existence of differences in the rooting competence of cuttings associated with ontogenetic characteristics, and corroborate the hypothesized existence of an important genetic component to ontogenetic maturation patterns and their effects on rooting by cuttings. Another important finding was that the average rooting of cuttings from epicormic shoots produced at different positions on the trunk was $26.6 \%$ when treated with IBA (Table 2). When plants were submitted to coppicing, the average rooting of cuttings not treated with IBA was $37.1 \%$, but this reached $55.2 \%$ when they were also treated with IBA (Table 3 ). This may indicate that more mature plants require more drastic rescuing techniques, such as coppicing, which involves the elimination of the aerial part of the plant, whereas more juvenile plants can be rescued by girdling alone.

In this study, we were able to rescue adult plants and produce mate plantlets by taking cuttings of epicormic shoots produced at different positions on the trunk, 
a possibility that was indicated in a previous study by Bisognin et al. (2017) that used epicormic shoots developed during post-fire regrowth. The success of rescuing adult mate plants and their propagation by cuttings depended on the stock plant in this study (Table 1), which confirmed that the adventitious rooting competence of epicormic shoots has an important genetic component that can be a limiting factor for the vegetative propagation of mate plants. Differences in the potential for rescuing by cuttings between the two adult mate plants were also found among epicormic shoots induced by pruning and girdling collected from different positions. The 13SM05 plant had greater rooting competence than the other stock plant, and there was no effect of the trunk position of the induced epicormic shoots on this for this plant; however, position did significantly affect rooting by cuttings of the 13SM01 stock plant (Table 2), which provides evidence of the negative effects of plant maturation on the adventitious rooting of plant cuttings. Therefore, the results of the present study are highly relevant because they show that while some plants can only be rescued from epicormic shoots at the basal portion of the plant, others can also be propagated from shoots produced throughout the trunk, maximizing the multiplication ratio and requiring fewer cycles of vegetative propagation for the commercial production of plantlets. This information justifies the evaluation of stock plants for the production of epicormic shoots, as well as for the rooting competence of cuttings collected from different positions on the trunk, when the objective is to use as many shoots as possible for propagation by cuttings. It is important to note that the treatment of cuttings with 3,000 $\mathrm{mg} \mathrm{L}^{-1}$ IBA increased the rooting percentages of both stock plants, which demonstrates the importance of using IBA when rescuing adult plants of mate by rooted cuttings from epicormic shoots induced by girdling, coppicing, or pruning the branches along the trunk. The successful use of these different strategies indicated that it is possible to identify stock plants with higher competence for adventitious rooting, including for shoots produced at different trunk positions. This information can be used when creating selection criteria for rescuing adult mate plants, propagating them by cuttings, and establishing a clonal mini-garden for the mass production of plantlets by mini-cuttings.

\section{CONCLUSIONS}

1. It is possible to rescue adult mate plants by taking cuttings from epicormic shoots induced by pruning, girdling, or coppicing.

Revista Árvore. 2018;42(3):e420312
2. The adventitious rooting competence of cuttings differs among adult plants of mate, and depends on the position on the trunk from which epicormic shoots are collected.

\section{REFERENCES}

Almeida FD, Xavier A, Dias JMM. Propagação vegetativa de árvores selecionadas de Eucalyptus cloeziana F. Muell. por estaquia. Revista Árvore. 2007;31(3):445-53.

Assis TF, Teixeira SL. Enraizamento de plantas lenhosas. In: Torres AC, Caldas LS, Buso JA. Cultura de tecidos e transformação genética de plantas. Brasília, DF: Embrapa-SPI/Embrapa-CNPH; 1998. p.183-260.

Bisognin DA. Breeding vegetatively propagated horticultural crops. Crop Breeding and Applied Biotechnology. 2011;S1:35-43.

Bisognin DA, Bandinelli $\mathrm{MG}_{2}$ Kielse P, Fischer $\mathrm{H}$. Rooting potential of mini-cuttings for the production of potato plantlets. American Journal of Plant Sciences. 2015;6(2):366-71.

Bisognin DA, Lencina KH, Kielse P, Fleig FD, Silveira R, Gimenes ES. Cuttings of post fire epicormic shoots of Ilex paraguariensis and Cabralea canjerana adult plants, Ciência Rural. 2017;47(3):1-6.

Bitencourt J, Zuffellato-Ribas KC, Wendling I, Koehler HS. Enraizamento de estacas de erva-mate (Ilex paraguariensis A. St.-Hill.) provenientes de brotações rejuvenescidas. Revista Brasileira de Plantas Medicinais. 2009;11(3):277-81.

Brondani GE, Wendling I, Brondani AE, Araujo MA, Silva ALL, Gonçalves AN. Dynamics of adventitious rooting in mini-cuttings of Eucalyptus benthamii x Eucalyptus dunnii. Acta Scientiarum. Agronomy. 2012;34(2):169-78.

Costa CT, Almeida MR, Ruedell CM, Schwambach J, Maraschin FS, Fett-Neto AG. When stress and development go hand in hand: main hormonal controls of adventitious rooting in cuttings. Frontiers in Plant Science. 2013;4:1-133.

Dutra TR, Massad MD, Sarmento MFQ, Oliveira JC. Ácido indolbutírico e substratos na alporquia

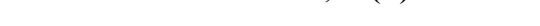


de umbuzeiro. Pesquisa Agropecuária Tropical. 2012;42(4):424-9.

Eldridge K, Davidson J, Hardwiid C, van Wyk G. Eucalypt domestication and breeding. Oxford: Clarendon Press; 1994.

Ferreira EM, Alfenas AC, Mafia RG, Leite HG, Sartorio RC, Penchel Filho RM. Determination of the optimum time for rooting of mini-cuttings of Eucalyptus spp. clones. Revista Árvore.2004;28(2):183-7.

Greenwood MS, Hutchison KW. Maturation as an developmental process. In: Ahuja MR, Libby WJ. Clonal forestry: genetics and biotecnology. Budapest: Springer-Verlag; 1993. p.14-33.

Hartmann HT, Kester DE, Davies JRFT, Geneve RL. Plant propagation: principles and practices. $8^{\text {th }}$. ed. Boston: Prentice Hall; 2011.

Husen A, Pal M. Metabolic changes during adventitious root primordium development in Tectona grandis Linn. f. (teak) cuttings as affected by age of donor plants and auxin (IBA and NAA) treatment. New Forests. 2007;33:309-23.

Kibbler H, Johnston ME, Williams RR. Adventitious root formation in cuttings of backhousia citriodora F. Muell 1. Plant genotype, juvenility and characteristics of cuttings. Scientia horticulturae. 2004;102:133-43.

Li SW, Xue LG, Xu SJ, Feng HY, An LZ. Mediators, genes and signaling in adventitious rooting. Botanical Review. 2009;75:230-47.

Mankessi F, Saya A, Baptiste C, Nourissier S, Monteuuis O. In vitro rooting of genetically related Eucalyptus urophylla x Eucalyptus grandis clones in relation to the time spent in culture. Trees. 2009;23(5):931-40.

Moon HK, Yi YS. Cutting propagation of Quercus acutissima clones after rejuvenation through serial grafting. Annals of Forest Science. 1993;50(1):314-8.

Oliveira LS, Dias PC, Almeida M. Avaliação genética do enraizamento de miniestacas de procedência de Eucalyptus cloeziana. Pesquisa Florestal Brasileira. 2015;35(84):391-7.
Pereira MO, Wendling I, Nogueira AC, Kalil Filho AN, Navroski MC. Resgate vegetativo e propagação de cedro-australiano por estaquia. Pesquisa Agropecuária Brasileira. 2015;50(4):282-9.

Rast ED, Beaton JA, Sonderman DL. Photographic guide to selected extemal defect indicators and associated internal defects in black walnut. Washington: USDA Forest Service, 1988. 24p. (Research Paper NE-617)

Resende MDV, Sturion JA, Carvalho AP, Simeão RM, Fernandes JSC. Programa de melhoramento da erva-mate coordenado pela Embrapa: resultados da avaliação genética de populações, progênies, indivíduos e clones. Colombo: Embrapa Florestas; 2000. 65p. (Embrapa Florestas. Circular técnica, 43).

Seitz RA. Manual de poda de espécies arbóreas florestais. Curitiba: FUPEF - Fundação de Pesquisas Florestais do Paraná; 1995. 56p.

Silva ET, Bicca Neto H, Foltran BN. Materiais de cobertura na produção de mudas de erva-mate (Ilex ParaguariensisSt. Hill). Scientia Agraria. 2007;8(1):103-9.

Singh S, Ansari SA. Mass multiplication of mature trees of Gmelina arborea Roxb. through ex vitro rooting of rejuvenated bud shoots. Research Journal of Forestry. 2014;8:25-31.

Stuepp CA, Bitencourt J, Wendling I, Koehler HS, Zuffellato-Ribas KC. Indução de brotações epicórmicas por meio de anelamento e decepa em ervam-mate. Ciência Florestal. 2016;26(3):1009-22.

Sturion JA, Resende MD. Programa de melhoramento genético da erva-mate no centro nacional de pesquisa de florestas da Embrapa. In: Anais do $1^{\circ}$ Congresso Sul Americano da ErvaMate, $2^{\mathrm{a}}$. Reúnião Técnica do Cone Sul sobre a Cultura da Erva-Mate. Curitiba: 1997. Colombo: Embrapa- CNPF; 1997. p.285-97. (Documentos, 33).

Wendling I, Brondani GE, Biassio A, Dutra LF. Vegetative propagation of adult Ilex paraguariensis trees through epicormic shoots. Acta Scientiarum Agronomy. 2013;35(1):117-25.

Wendling I, Trueman SJ, Xavier A. Maturation and related aspects in clonal forestry - Part I: 
concepts, regulation and consequences of phase change. New Forest. 2014;45(4):449-71.

Wendling I, Xavier A. Gradiente de maturação e rejuvenescimento aplicado em espécies florestais.
Floresta e Ambiente. 2001;8(1):187-94.

Xavier A, Wendling I, Silva RL. Silvicultura clonal: princípios e técnicas. $2^{\mathrm{a}}$. ed. Viçosa, MG: Universidade Federal de Viçosa; 2013.

Revista Árvore. 2018;42(3):e420312 